\title{
Toddler with isolated rib tuberculosis
}

\section{Ravibindu Ranawaka ${ }^{1}$, Sandini Gunaratne ${ }^{2}$, Jerard Fernando ${ }^{3}$, Wasantha Rathnayake ${ }^{4}$}

Sri Lanka Journal of Child Health, 2018; 47(4): 366-367

DOI: http://dx.doi.org/10.4038/sljch.v47i4.8611

(Key words: Rib tuberculosis, child)

\section{Introduction}

Mobile benign chest wall lumps are frequent encounters in healthy children. A mass with deep attachments however, is suspicious of neoplastic origin. An isolated chest wall mass of tuberculous origin in a healthy baby with normal BCG scar is extremely rare according to the literature ${ }^{1}$.

\section{Case report}

A 20 month old healthy boy presented with an incidentally detected right lateral chest wall mass. The fairly well defined oval shaped mass of about $4 \mathrm{~cm}$ size was attached to the underlying rib. Clinical impression of the lump was of neoplastic origin and Ewing sarcoma family of tumours was the suspected pathological entity ${ }^{2}$. Chest $\mathrm{x}$-ray showed a single lytic lesion of the $5^{\text {th }}$ rib near the costochondral junction. Computed tomography (CT) scan identified the isolated lesion having a soft tissue component extending from beneath the skin causing rib destruction and indenting underlying pleura (Figure 2). There was no involvement of the lung parenchyma. The radiology was compatible with the clinical impression of Ewing sarcoma of the rib.

His full blood count, blood picture and erythrocyte sedimentation rate were normal. An incision biopsy was done instead of image guided tru-cut biopsy as the centre of the lesion was radiologically necrotic. Histology identified the presence of epithelioid histiocytes forming granuloma with caseation, lymphocytes and Langhans giant cells that were diagnostic of tuberculosis $(\mathrm{TB})^{3}$. There was peripheral bone necrosis. His BCG scar was normal and Mantoux test reading was $10 \mathrm{~mm}$. Culture of gastric aspirate was negative for TB.

\section{${ }^{1}$ Consultant Paediatric Surgeon, ${ }^{2}$ Consultant Histopathologist, ${ }^{3}$ Consultant Radiologist, ${ }^{4}$ Consultant Oncologist, Lady Ridgeway Hospital for Children, Colombo, Sri Lanka \\ *Correspondence: rravibindu@yahoo.com}

(Received on 07 March 2017. Accepted after revision on April 2017)

The authors declare that there are no conflicts of interest

Personal funding was used for the project.

Open Access Article published under the Creative

Commons Attribution CC-BY CC LY License

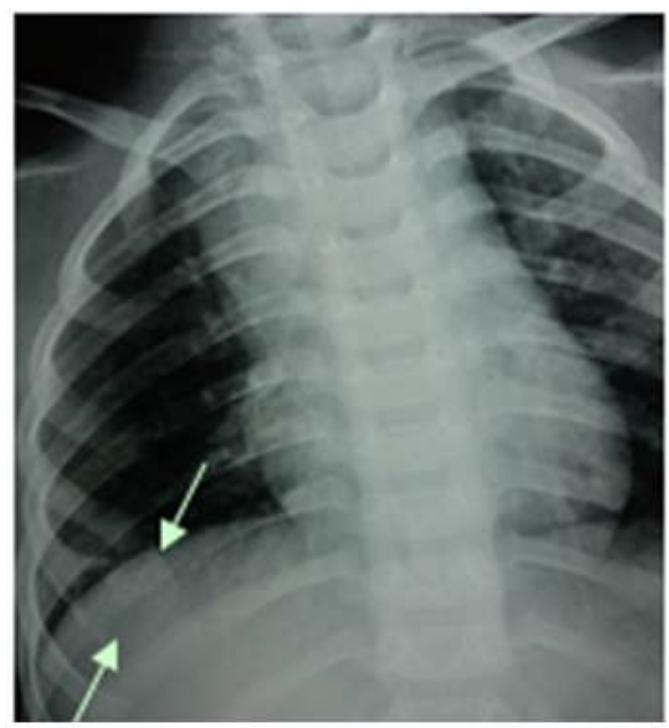

Figure 1: Chest $x$-ray showing rib erosion

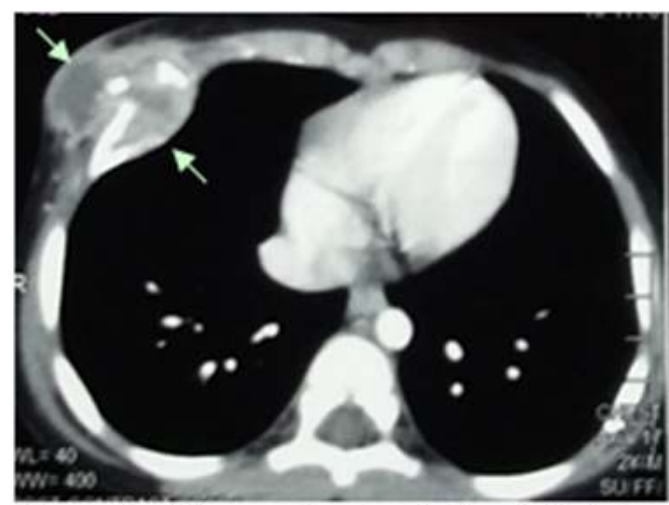

Figure 2: CT scan showing isolated rib lesion

Biopsy was repeated to exclude the rare possibility of co-existing malignancy. Second histology findings were typical of $\mathrm{TB}$ and the diagnosis of TB of the rib was confirmed. Histology of one of the few small adjacent cervical lymph nodes was reactive. Xpert MTB/RIF (Xpert) test which gives faster and more accurate report than yield of culture in extra-pulmonary tuberculosis of bone ${ }^{4}$ confirmed the diagnosis of TB.

Anti-tuberculous therapy was commenced under supervision of chest physicians pending tuberculous culture of the rib lesion ${ }^{5}$. The culture however did not yield a growth of Mycobacterium tuberculosis. Negative culture of TB of rib is common according to the literature ${ }^{1}$. Chest $\mathrm{x}$-ray 
taken after three months of treatment identified new bone formation and reduction of size of the necrotic rib centre compatible with resolving TB.

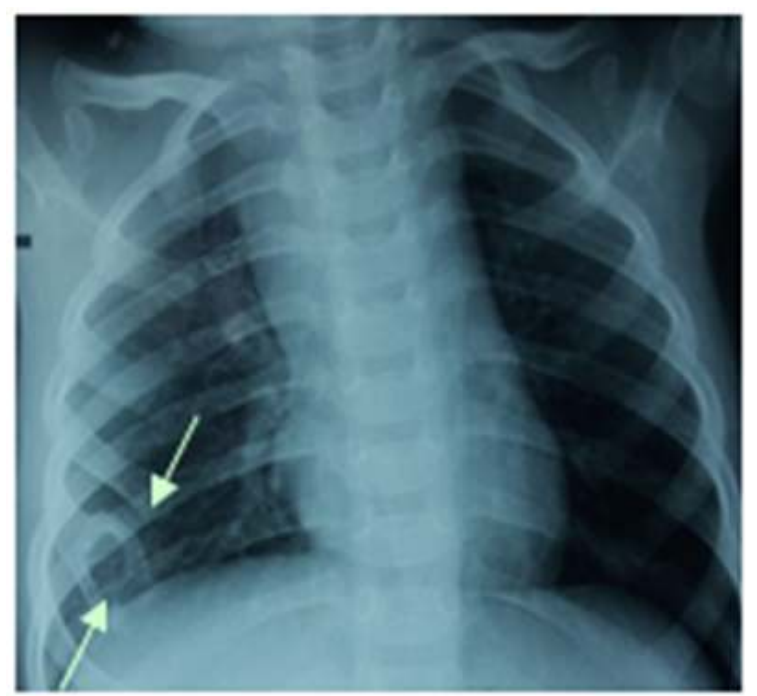

Figure 3: Chest x-ray three months after starting anti-TB therapy showing resolution of rib lesion

On completion of anti-tuberculous therapy, the baby remained healthy having marked reduction of the chest wall mass.

\section{Discussion}

Bone and joints are affected in about $5 \%$ patients with TB with a predilection to vertebral bodies and large synovial joints ${ }^{6}$. According to the literature, there are few reports of TB of rib presenting as a discharging sinus ${ }^{7}$ but presentation as an isolated chest wall mass is very rare ${ }^{1}$. Chest wall TB is thought to occur by direct inoculation from lymph nodes or via haematogenous spread ${ }^{6}$. BCG vaccination is reported to have an efficacy of $50 \%$ against Mycobacterium tuberculosis infection ${ }^{8}$. It is difficult to explain the origin of the isolated tuberculous rib lesion in this healthy baby with normal BCG scar.

Clinical diagnosis of an isolated chest wall mass with deep attachments in a healthy baby is often suspicious of neoplastic origin although exceptions are encountered rarely. In dubious instances judicious use of radiological, histological, immunological and microbiological techniques would facilitate the diagnosis.

\section{References}

1. Balci YI, Akpinar F, Firinci F, Ozdemir E, Mete E, Cevahir N et al. A 12-month-old boy with a soft mass over his left 10th rib. Pediatric Annals 2015; 44(11):477, 482-3. https://doi.org/10.3928/009044812015111 2-05

PMid: 26587814
2. O’Donnell RJ, DuBois SG, Haas-Kogan DA. Sarcomas of Bone. In: Devita VT, Lawrence TS, Rosenberg SA. editors. Cancer Principles and Practice of Oncology. Walters Kluwer Health; 2015. p. 1292-313.

3. Cotran RS, Kumar V, Collins T. Granulomatous inflammation. In: Cotran RS, Kumar V, Collins T. editors. Robbins Pathologic basis of disease. Singapore: Saunders; 1999. p. 83-84.

4. Held M1, Laubscher M, Mears S, DixPeek S, Workman L, Zar $\mathrm{H}$, et al. Diagnostic Accuracy of the Xpert MTB/RIF Assay for Extra-pulmonary Tuberculosis in children with musculoskeletal infections. Pediatric Infectious Disease Journal 2016; 35 (11):1165-8. https://doi.org/10.1097/INF.00000000000 01271

PMid: 27286562

5. Sarukkali C, Lamabadusooriya S, Lucas GN, Perera BJC, Somasundaram, Senarathne $\mathrm{V}$ et al. Guidelines for Management of Tuberculosis in Children, Ministry of Health Sri Lanka National Programme for Tuberculosis Control and Chest Diseases 2008.

6. Solomon L, Warwick D, Nayagam S. Tuberculosis. In: Solomon L, Warwick D, Nayagam S. editors. Apley's System of Orthopaedics and Fractures London: Arnold; 2001. p. 42-45.

PMid: 11190990

7. Agrawal V. Joshi MK, Jain BK, Mohanty D, Gupta A. Tuberculotic osteomyelitis of rib - a surgical entity. Interactive Cardiovascular and Thoracic Surgery 2008; 7(6): p.1028-30.

https://doi.org/10.1510/icvts.2008.179127 PMid: 18723526

8. Weerasinghe A. BCG. In: Jayasuriya L, Wimalarathne O, Perera J, Weerasinghe A editors. SLMA Guidelines and information on vaccines. SLMA. Colombo. 2014. p.25-28. 